\title{
INTERPERSONAL INTELEGENSI, BELAJAR KELOMPOK DAN PEMANFAATAN INTERNET TERHADAP MATAPELAJARAN EKONOMI
}

\author{
Maria Valentina Ikun \\ e-mail:valenikun95@gmail.com \\ Lilik Sri Hariani \\ e-mail: liliksrihariani@unikama.ac.id \\ Affan Afian \\ e-mail: affanafian@unikama.ac.id
}

(Program Studi Pendidikan Ekonomi, Fakultas Ekonomika dan Bisnis, Universitas Kanjuruhan, Malang)

\begin{abstract}
ABSTRAK: hasil belajar merupakan suatu perubahan tingkah laku pada siswa setelah siswa melakukan proses belajar disekolah, hasil belajar bisa berupa nilah dan prestasi yang didapatkan. Penelitian ini bertujuan untuk mengetahui seberapa besar pengaruh pengaruh interpersonal intelegensi, belajar kelompok, dan pemanfaatan internet terhadap hasil belajar. Penelitian menggunakan pendekatan kuantitatif dengan jenis penelitian ex post facto dengan mengunakan regresi linear berganda. Populasi adalah siswa kelas XI IPS SMA N 10 Malang yang berjumlah 144 siswa. Sampel sebanyak 72 siswa yang di ambil mengunakan rumus slovin. Teknik pengumpulan data menggunakan angket dan dokumentasi. Analisis data menggunakan regresi linier berganda Hasil penelitian menunjukkan bahwa secara brsama-sama interpersonal intelegensi, belajar kelompok, dan pemanfaatan internet berpengaruh terhadap hasil belajar. Tidak terdapat pengaruh yang signifikan Interpersonal intelegensi secara parsial terhadap hasil belajar. Terdapat pengaruh belajarkelompok terhadap hasil belajar. Tidak terdapat pengaruh yang signifikan pemanfaatan internet secara parsial terhadap hasil belajar.
\end{abstract}

Kata kunci - Interpersonal Intelegensi, Belajar Kelompok, Pemanfaatan Internet, Hasil Belajar

ABSTRACT : learning outcomes is a change in behavior in students after students do the learning process at school, learning outcomes can be in the form of values and achievements. This study aims to determine how much influence the influence of interpersonal intelligence, group learning, and the use of the internet on learning outcomes. The study uses a quantitative approach to the type of ex post facto research using multiple linear regression. The population is class XI IPS students of SMA N 10 Malang, totaling 144 students. A sample of 72 students were taken using the Slovin formula. Data collection techniques using questionnaires and documentation. Data analysis using multiple linear regression The results of the study show that interpersonal intelligence together, group learning, and internet use influence the learning outcomes. There is no significant influence partially Interpersonal intelligence on learning outcomes. There is an effect of group learning on learning outcomes. There is no significant influence partial use of the internet on learning outcomes.

Keywords - Interpersonal Intelligence, Group Learning, Internet Utilization, Learning Outcomes 


\section{PENDAHULUAN}

Salah satu cara untuk mengukur mutu sumber daya individu dalam dunia pendidikan ialah hasil belajar. Hasil belajar merupakan pencapaian peserta didik selama melakukan kegiatan belajar di sekolah. "Tujuan dari penilaian hasil belajar merupakan untuk menilai kemampuan belajar setiap siswa sehingga dapat diketahui kelebihan dan kelemahannyannya dalam berbagai bidang studi atau mata pelajaran yang ditempuh siswa dan seberapa jauh keefektifannya dalam mengubah tingkah laku para siswa ke arah tujuan pendidikan yang diharapkan" (Nana Sudjana (2014:4). Hasil belajar mengcakup tiga aspek yaitu (1)Kognitif, aspek kognitif merupakan ranah yang mencakup kegiatan otak. Segala sesuatu yang menyangkut aktivitas otak merupakan termasuk dalam ranah kognitif. Aspek Kogninitif dibagi menjadi 6 aspek yaitu; aspek Pengetahuan/hafalan/ingatan (knowledge), Pemahaman (comprehension), Penerapan (application) Analisis (analysis), Sintesis (syntesis), Penilaian/penghargaan/evaluasi (evaluation).

Tujuan aspek kognitif berorientasi pada kemampuan berfikir yang melingkupi kemampuan intelektual yang lebih spesifik, yaitu mengingat, sampai pada kemampuan memecahkan masalah yang menuntut siswa untuk menghubungakan dan menggabungkan be berapa ide, gagasan, metode atau prosedur yang dipelajari untuk memecahkan masalah tersebut (2) Afektif, aspek afektif merupakan ranah yang berkaitan dengan sikap dan nilai siswa. Aspek afektif melingkupi watak atau perilaku siswa seperti perasaan, minat, sikap, emosi, dan nilai. (3) Psikomotorik, aspek psikomotor iyalah aspek yang berhubungan dengan keterampilan tau kemampuan bertindak setelah siswa menerima pengalaman belajar tertentu. Hasil belajar keterampilan dapat diukur melalui: (1) pengamatan langsung dan penilaian tingkah laku peserta didik selama proses pembelajaran berlangsung dikelas, (2) sesudah mengikuti pembelajaran dikelas, yaitu memberikan tes kepada siswa untuk mengukur pengetahuan, keterampilan, dan sikap, (3) setelah beberapa waktu pembelajaran selesai dan dalam lingkungan kerjanya.

Salah satu factor yang mempengaruhi hasil belajar peserta didik ialah interpersonal intelegensi. Interpersonal intelegensi merupakan salah satu kecerdasan yang berkaitan dengan cara siswa untuk menjalin, membina, menciptakan mempertahankan hubungan dengan teman lain dalam rangka memecahkan masalah, menciptakan sebuah relasi sosial yang tidak merugikan. Atau interpersonal intelegensi kemampuan siswa untuk memahami dan berinteraksi dengan teman secara efektif. Siswa yang mempunyai kecerdasan interpersonal akan lebih mudah untuk berinteraksi dengan orang lain dan mudah dalam merespons suasana hati orang lain, maupun keinginan orang lain. Siswa yang memiliki kecerdasan interpersonal baik maka siswa itu akan lebih muda bergaul dengan teman lain dan mau menerima pendapat dari orang lain, berteman juga dalam konteks proses belajar mengajar selalu menyukai belajar bersama dan mudah berempati terhadap orang lain.

Apa bila siswa sudah memiliki interpersonal intelegensi maka dalam proses pembelajaran siswa itu akan aktif dan mau membagi pengetahuan dengan teman-temannya. Dan siswa itu akan menerima pendapat dari orang lain serta menerima masukan dari orang lain. Dengan menerima masukan dari orang lain maka akan menambah pengetahuan siswa tersebut. Kecerdasan interpersonal menjadi penting karena pada dasarnya manusia tidak bisa sendiri, banyak kegiatan dalam kehidupan manusia yang saling terkait dengan yang lainnya. Seseorang yang gagal dalam mengembangkan kecerdasan interpersonalnya akan banyak mengalami hambatan dalam dunia sosialnya. Bisa dibayangkan ketika seseorang siswa harus bekerja kelompok dalam pembelajaran dikelas, kemudian kecerdasan interpersonalnya kurang menyebabkannya menyingkir dari kegiatan 
bersama tersebut. Hal ini tentu akan sangat merugikan siswa tersebut.Hal ini sebagaimana dikemukakan oleh Prasetyo (2010: 74), bahwa kecerdasan interpersonal merupakan kapasitas untuk memahami maksud, motivasi, dan keinginan orang lain.

Faktor lain yang mempengaruhi hasil belajar yaitu belajar kelompok. Belajar kelompok merupakan sebuah bentuk belajar dimana siswa dibentuk dalam beberapa kelompok untuk belajar bersama, untuk menyelesaikan tugas belajar yang sudah dibagikan oleh guru.. Dengan belajar kelompok guru membiasakan siswa untuk bisa bergaul atau belajar dengan teman-temannya, bagaimana mengemukakan pendapat dan menerima pendapat dari temannya yang lain, belajar secara kelompok ikut pula melaksanakan tujuan pendidikan dan pengajaran, untuk belajar mengatasi kesulitan-kesulitan, terutama dalam hal pelajaran, secara bersama-sama, belajar hidup bersama agar nantinya tidak asing di dalam masyarakat yang lebih luas dan membangun rasa kegotong royong yang merupakan sifat dari bangsa Indonesia. Belajar kelompok mempermudah siswa untuk belajar, saling berbagi informasi tentang pembelajaran. Siswa mampu mengemukakan pendapat, menerima pendapat dan meneladani materi dengan cepat karena siswa bisa menyelesaikan masalah bersama-sama. Dengan berjalannya belajar kelompok maka pengetahuan siswa akan bertambah tentang materi pembelajaran. Dengan belajar kelompok terciptanya suatu sikap siswa yang baik siswa mampu bertoleransi sesama teman dengan menerima pendapat teman dan memiliki ketrampilan bekerjasama dalam kelompok. (Djamarah, 2010:56).

Salah satu factor penunjang lain untuk meningkatkan hasil belajar siswa yaitu pemanfaatan internet. Keuntungan mengunakan internet "Pertama, sebagai pendorong komunitas pendidikan (termasuk guru) untuk lebih apresiatif dan proaktif dalam memaksimalkan potensi pendidikan. Kedua, memberikan kesempatan luas kepada peserta didik dalam memanfaatkan setiap potensi yang ada, yang dapat diperoleh dari sumber-sumber yang tidak terbatas". Pemanfaatan internet disini memiliki arti penting dan mempunyai kegunaan yang besar dalam pendidikan. Dengan adanya internet siswa bisa lebih mendapat banyak pengetahuan, karena apa yang tidak ada di buku mereka bisa mencari langsung di internet.Internet di bidang pendidikan sangat bermanfaat di dalam proses belajar mengajar di sekolah, dimana semua siswa bisa melengkapi ilmu pengetahuannya, sedangkan guru bisa mencari bahan ajar yang sesuai dan inovatif melalui internet. Siswa dapat mencari apa saja di internet, mulai dari mata pelajarn hingga ilmu pengetahuan umum semuanya bisa dicari diinternet. Sedangkan guru bisa mencari informasi yang dapat dijadikan sumber untuk mengajarkan materi kepada siswanya selain dari buku. Pemanfaatan Internet sebagai media pembelajaran dapat dianggap sebagai suatu hal yang sudah biasa digunakan di kalangan pelajar. Untuk itu sekolah-sekolah bisa menjadikan Internet sebagai fasilitas untuk belajar selain dari buku dan agar mampu menjadi solusi dalam mengatasi masalah yang selama ini terjadi, misalnya kurangnya buku yang ada di perpustakaan, kekurangan tenaga ahli, jarak rumah dengan lembaga pendidkan yang jauh, biaya yang mahal dan waktu belajar yang kurang. Menyadari bahwa di Internet dapat ditemukan bermacam informasi apa saja, maka pemanfaatan Internet menjadi suatu kebutuhan guru dan murit, (Riyanto 2012 dan Rofikoh 2013). 


\section{TINJAUAN PUSTAKA}

Menurut Amelia, (2013). Hasil belajar ialah perubahan dalam hal kepandaian tingkah laku ataupun kemampuan yang mencakup bidang kognitif, afektif, dan psikomotorik yang di miliki siswa setelah menerima pembelajaran disekolah..

Menurut Rusman (2012:124) Faktor-faktor yang mempengaruhi hasil belajar antara lain ialah faktor internal dan faktor eksternal

1. Faktor internal meliputi Faktor fisiologis faktor psikologis.

Secara umum keadaan fisiologis, seperti kesehatan yang pertama, tidak dalam keadaan lelah dan capek, tidak dalam keadaan cacat jasmani dan lainnya. Hal tersebut dapat mempengaruhi siswa dalam menerima materi pelajaran. Faktor Psikologis, Setiap siswa pada dasarnya memiliki kondisi psikologis yang berbeda-beda, tentunya hal ini ikut mempengaruhi hasil belajarnya. Beberapa faktor psikologis mencakup intelegensi, perhatian, minat, bakat, motif, motivasi, kognitif dan daya nalar peserta didik.

2. Faktor Eksternal meliputi Faktor Lingkungan.

Faktor lingkungan bisa mempengurhi hasil belajar. Faktor lingkungan ini meliputi lingkungan fisik dan lingkungan sosial. Lingkungan alam seperti suhu, kelembaban dan lain-lain. Belajar pada tengah hari di ruangan yang kurang akan sirkulasi udara akan sangat berpengaruh dan akan sangat berbeda pada pembelajaran pada pagi hari yang kondisinya masih segar dan dengan ruangan yang cukup untuk bernafas lega.

\section{Interpersonal Intelegensi}

Menurut Chatib dan Said (2012:94) yang menjelaskan bahwa kecerdasan interpersonal ialah kemampuan memahami dan berinteraksi dengan orang lain secara efesien.Pengaruh kecerdasan sosial terhadap hasil belajar siswa baik secara intrinsik dan ekstrinsik serta manfaat yang diharapkan dapat menyehatkan jiwa dan raganya, membuat suasana nyaman, dapat meredakan emosional serta dapat membangkitkan semangat. Sehubungan dengan manfaat interpersonal juga mempunyai kemampuan untuk mengembangkan dirinya sendiri, berdasarkan adanya kesadaran situasional, kemampuan membawa diri, intensitas, kemampuan kejelasan serta kemampuan memamahami dirinya.

Menurut Safaria (2010), terdapat tiga tingkat dimensi interpersonal intelegensi yaitu:

\section{a Social Sensitivity}

Social sensitivity atau yang disebut dengan senstivitas sosial, merupakan kemampuan siswa dalam merasakan dan mengamati berbagai macam reaksi pada siswa yang kemudian ditunjukkan baik dalam bentuk lisan ataupun non lisan. Indikator dalam sensitivitas sosial, yaitu sikap empati dan sikap prososial.

\section{b Social Insight}

Merupakan kemampuan dalam memahami serta mencari solusi dari permasalahan yang efektif di dalam interaksi sosial. Sehingga masalah-masalah yang ada tidak akan menghambat hubungan sosial yang sudah terbentuk sebelumnya. Dasar dalam sosial insight adalah berkembangnya kesadaran siswa secara baik. Kesadaran diri inilah yang akan membuat seseorang lebih mampu untuk memahami dirinya sendiri mulai dari internal hingga eksternal. indikator di dalam social insigh antara lain: kesadaran diri, pemahaman situasi sosial, keterampilan memecahkan masalah. 


\section{c Social communication}

Penguasaan ketampilan komunikasi sosial ialah kemampuan siswa untuk menggunakan proses komunikasi dalam menjalin dan membangun hubungan interpersonal yang sehat. Dalam proses menciptakan, membangun dan mempertahankan relasi sosial, mala seseorang membutuhkan sarannya. Indikator dari Social communication adalah: komunikasi efektif dan mendengarkan efektif.

\section{Belajar Kelompok}

Belajar kelompok ialah upaya saling membantu antara dua orang atau lebih, antara individu dengan kelompok dan antara kelompok dengan kelompok lainnya dalam melaksanakan tugas atau menyelesaikan masalah yang dihadapi dan atau mengatur berbagai program yang bersifat menjanjikan guna mewujudkan manfaat dan kesejahteraan bersama. Makna kegiatan belajar kelompok adalah tercipanya suasana pembelajaran yang aktif antara siswa dalam mencapai tujuan pembelajaran yang telah dirumuskan (Menurut Parker 2012:29). Dalam hal ini Belajar kelompok ialah upaya saling membantu antara dua orang atau lebih, antara individu dengan kelompok dan antara kelompok dengan kelompok lainnya dalam melaksanakan tugas atau menyelesaikan problema yang dihadapi dan atau menggarap berbagai program yang bersifat prospektif guna mewujudkan kemaslahatan dan kesejahteraan bersama. Dalam hal ini kaitannya dengan hasil belajar siswa dapat belajar tentang pengetahuan, ketrampilan dan sikap dari teman sebaya.

Sedangkan Roestiyah (2011:32) keuntungan menggunakan teknik kerja kelompok adalah:

1. Membiasakan siswa bergaul dengan teman-temannya, bagaimana mengemukakan pendapat dan menerima pendapat dari temannya yang lain.

2. Belajar secara kelompok turut pula melaksanakan tujuan pendidikan dan pengajaran.

3. Untuk belajar mengatasi kesulitan-kesulitan, terutama dalam hal pelajaran, secara bersama-sama.

4. Belajar hidup bersama agar nantinya tidak segan di tengah masyarakat yang lebih luas.

5. Memupuk rasa kegotong royong yang merupakan sifat dari bangsa Indonesia.

\section{Pemanfaatan Internet}

Pemanfaatan internet mempunyai pengaruh terhadap hasil belajar, hal ini dibuktikan hasil penelitian oleh Riyanto (2014) yang menyatakan bahwa terdapat pengaruh yang positif dan signifikan antara pemanfaatan internet terhadap hasil belajar siswa. Rofikoh (2013). Internet dikatakan memiliki pengaruh yang cukup besar terhadap bidang pendidikan, karena internet memiliki kelebihan yang bisa mempengaruhi peserta didik, dengan internet peserta didik lebih cepat memahami sebuah pengetahuan atau teori melalui media-media yang berkaitan dengan teknologi informasi dibandingkan dengan penyampaikan secara formal. Berdasarkan hasil penelitian oleh Riyanto(2012) dan Rofikoh (2013) menyatakan bahwa pemanfaatan internet memiliki pengaruh yang sangat tinggi terhadap hasil belajar siswa.

Palmer W. Agnew dkk ( 2015: 27) menjelaskan bahwa pemanfaatan internet secara efektif dan efisien akan meningkatkan hasil belajar peserta didik. Namun bila internet tidak dimafaatkan dengan bijak oleh peserta didik maka internet akan membawa pengaruh yg negatif bagi peserta didik. 
Pemanfaatan internet mempunyai berpengaruh terhadap hasil belajar, hal ini dibuktikan hasil penelitian oleh Riyanto (2014) yang menyatakan bahwa terdapat pengaruh yang positif dan signifikan antara pemanfaatan internet terhadap hasil belajar siswa. Rofikoh (2013) Internet dikatakan memiliki dampak yang cukup besar terhadap bidang pendidikan karena internet memiliki keunggulan yang bisa mempengaruhi Peserta didik, dengan internet Peserta didik lebih mudah memahami suatu pengetahuan atau teori melalui media-media yang berkaitan dengan teknologi informasi dibandingkan dengan penyampaikan secara biasa. Berdasarkan Hasil penelitian oleh Riyanto(2012) dan Rofikoh (2013) menyatakan bahwa pemanfaatan Internet mempunyai pengaruh yang tinggi terhadap hasil belajar siswa.

\section{METODE}

Jenis penelitian ini termasuk penelitian expost facto yang mengkaji pengaruh antara variabel. Jenis penelitian ini menggunakan pendekatan kuatitatif, karena data dalam diwujudkan dalam bentuk angka dan dianalisis menggunakan analisis statistic dibantu dengan menggunakan SPSS versi 16.00 for a windows. Penelitian ini dirancang untuk mengetahui berapa besar pengaruh variabel indenpenden terhadap variabel dependen. Penelitian telah dilaksanakan di SMA N 10 Malang. Populasi di dalam penelitian ini adalah siswa kelas XI IPS SMA Negeri 10 Malang yang berjumlah 144 siswa dan sampel penelitian 72 siswa, dengan teknik pengamblan sampel menggunakan rumus Slovin. Variabel dalam penelitian ini terdiri variabel bebas (independent variable) yaitu interpersonal intelegensi, belajar kelompok, dan pemanfaatan internet. Variabel terikat (dependent variable) yaitu hasil belajar. Data variabel X1, X2 dan X3 dikumpulkan menggunakan instrumen kuesioner (angket) sedangkan untuk varabel $\mathrm{Y}$ menggunakan Nilai raport smester 1. Adapun teknik pengambilan data dalam penelitian ini adalah dengan menggunakan angket dan dokumentasi. Kegiatan analisis data adalah "kegiatan setelah data dari seluruh responden atau data lain terkumpul. Kegiatan analisis data adalah mengelompokkan data berdasarkan variabel dan jenis responden, mentabulasi data berdasarkan variabel dari seluruh responden, menyajikan data tiap variabel yang diteliti, melakukan perhitungan untuk menjawab rumusan masalah dan melakukan perhitungan untuk hipotesis yang telah diajukan". Analisis data yang digunakan dalam penelitian ini adalah analisis regresi linear berganda.

\section{HASIL DAN PEMBAHASAN}

Deskripsi hasil penelitian yang diperoleh dari hasil pengumpulan data dengan instrument penelitian skala likert. Penelitian ini mengambarkan dari masing-masing variabel penelitian yaitu Interpersonal Intelegensi, Belajar Kelompok dan Pemanfaatan intenet terhadap Hasil belajar siswa kelas XI IPS SMA N 10 Malang. Deskripsi data yang disajikan mencakup mean, median, standart deviation, variance, skor minimum dan maksimum. Pada analisis data pada uji asumsi klasik memperoleh hasil yaitu di uji normalitas regresi telah memenuhi persyaratan normalitas, uji multikolinearitas memperoleh hasil tidak ada gejala multikolinearitas dan dinyatakan normal karena nilai VIF nya lebih kecil dari 5, pada uji heteroskedastitas memperoleh hasil tidak terjadi Heterokedastisitas karena diagram pencar residual tidak membentuk pola tertentu dan pada uji autokorelasi memperoleh hasil tidak terjadi autokorelasi, atau model regresi memenuhi persyaratan asumsi klasik tentang autokorelasi karena nilai signifikannya lebih kecil dari 0.05 
Berdasarkan hasil penelitian statistic dengan bantuan SPSS 16.00 for windows pada pengujian hipotesis diperoleh tabel model Anova yang menunjukan uji F statistic. Adapun hasil uji F pada Tabel 1 anova berikut:

Tabel 1 Hasil Uji ANOVA (Uji F)

\begin{tabular}{|c|c|c|c|c|c|}
\hline \multicolumn{6}{|c|}{ ANOVA $^{a}$} \\
\hline Model & $\begin{array}{l}\text { Sum of } \\
\text { Squares }\end{array}$ & Df & Mean Square & $\mathrm{F}$ & Sig \\
\hline 1 Regression & 259.400 & 3 & 86.467 & 4.928 &, $004^{\mathrm{b}}$ \\
\hline Residual & 1193.045 & 68 & 17.545 & & \\
\hline Total & 1452.444 & 71 & & & \\
\hline \multicolumn{6}{|c|}{ a. Dependent Variable: $Y$} \\
\hline b. Predictors: & stant), X3, X1, & & & & \\
\hline
\end{tabular}

Berdasarkan Tabel 1 hasil tes Anova diperoleh nilai F-hitung sebesar 4.928 dengan tingkat signifikan 0,004, karens nilsi tingkat signifikansi lebih kecil dari 0.05 maka hasil penelitian ini menerima hipotesis penelitian H1 yaitu: ada pengaruh yang signifikan secara simultan antara Interpersonal Intelegensi, Belajar Kelompok dan Pemanfaatan intenet terhadap Hasil belajar.

Berdasarkan hasil perhitungan statistic dengan bantuan program SPSS 16.00 for windows diperoleh Tabel berdasarkan hasil perhitungan statistik dengan bantuan computer melalui program SPSS Versi 16.00 for windows diperoleh tabel coefficients yang menunjukkan uji $t$ statistik. Uji $t$ digunakan untuk menguji signifikan pengaruh masing-masing dari variabel independen yang terdiri dari Interpersonal Intelegensi, Belajar Kelompok dan Pemanfaatan intenet terhadap variabel dependen yaitu Hasil belajar. Adapun hasil uji t pada Table 2 berikut:

Tabel 2 Hasil uji t (uji signifikan parsial)

\begin{tabular}{lcrl}
\hline Variabel & $\mathrm{t}$ & \multicolumn{1}{l}{ Sig } & Keterangan \\
\hline Constant & 7,629 &, 000 & Signifikan \\
\hline Interpersonal Intelegensi & 1,735 &, 087 & Tidak Signifikan \\
\hline Belajar kelompok & 2,845 &, 006 & Signifikan \\
\hline Pemanfaatan Internet &,- 701 &, 485 & Tidak Signifikan \\
\hline
\end{tabular}

a. Dependen variabel:Hasil Belajar

Sumber: Hasil penelitian

Berdasarkan Tabel 2 hipotesis penelitian untuk menguji hipotesis kedua (H2) nilai t-hitung untuk variabel $X_{1}$ (interpersonal intelegensi) sebesar 1,735 dengan tingkat signifikan sebesar, 087. Karena tingkat signifikannya lebih besar dari 0,05, maka variabel $X_{1}$ (interpersonal intelegensi) tidak berpengaruh terhadap variabel Y (hasil belajar. Hipotesis penelitian untuk menguji hipotesis kedua (H3) adalah sebagai berikut: nilai t-hitung untuk variabel $\mathrm{X}_{2}$ (belajar krlompok) sebesar 2,845 dengan tingkat signifikan sebesar ,006. Karena tingkat signifikannya kurang dari 0,05, maka variabel $\mathrm{X}_{2}$ (belajar kelompok) berpengaruh terhadap variabel $\mathrm{Y}$ (hasil belajar). Hipotesis penelitian untuk menguji hipotesis kesatu (H4) adalah sebagai berikut: nilai t hitung untuk variabel $\mathrm{X}_{3}$ (pemanfaatan internet) seb esar ,701 dengan tingkat signifikan sebesar ,485. Karena tingkat signifikannya lebih besar dari 0,05, mak 
a variabel $\mathrm{X}_{3}$ (pemanfaatan internet) tidak berpengaruh terhadap variabel $Y$ (hasil belajar). Berikut ini penjelasan dari hasil penelitian yang telah dilakukan oleh peneliti, yaitu sebagai berikut:

Seorang siswa untuk meningkatkan hasil belajar harus memiliki niat dalam diri untuk belajar. Siswa yang belajar dengan tekun akan memperoleh hasil belajar yang baik pula. Cara yang dapat dilakukan untuk meningkatkan hasil belajar yaitu interpersonal intelegensi, kerena ketika interpersonal intelegensi siswa sudah baik maka akan mempermudah siswa untuk bergaul dan berlajar bersama temannya. Selain itu dari belajar kelompok, model pembelajaran yang digunakan oleh guru sangat membantu anak dalam proses belajar, serta dengan adanya pmanfaatan internet dapat mempermudah siswa untuk mencari materi atau reverensi lain selain buku yang disediakan guru di sekolah. Penelitian ini dibuktikan melalui perhitungan statistika diperoleh tabel anova yang menunjukkan hasil uji F 4.928 dengan tingkat, $004^{\mathrm{b}}$ lebih kecil dari 0,05.

Interpersonal intelegensi, belajar kelompok dan pemanfaatan internet siswa kelas XI IPS SMA N 10 Malang sudah baik itu, hal ini diperoleh dari jawaban responden pada kuesioner mengenai interpersonal intelegensi, belajar kelompok dan pemanfaatan internet pada saat penelitian. Interpersonal intelegensi, belajar kelompok dan pemanfaatan internet sangat berpengaruh terhadap hasil belajar. Ketika interpersonal intelegensi siswa sudah baik maka akan mempermudah siswa untuk bergaul, berinteraksi dan berlajar bersama temannya mempermudah siswa itu untuk menerima, memahami, dan menghargai temannya. Karena ketika siswa sudah mau memahami, menghargai, menerima pendapat dari teman maka akan mempermudah siswa untuk belajar. Selain itu dari belajar kelompok, model pembelajaran yang digunakan oleh guru sangat membantu anak dalam proses belajar, karena dengan belajar kelompok siswa yang tidak aktif di kelas menjadi aktif, siswa yang malu bertanya menjadi tidak malu, siswa yang malas mengerjakan tugas jadi rajin karena motivasi dari teman lain. Serta dengan adanya pmanfaatan internet dapat mempermudah siswa untuk belajar, siswa bisa mencari materi atau reverensi lain selain buku yang disediakan guru di sekolah selain dari buku siswa bisa mencari materi di internet, menonton vidio-vidio yang yang berhubungan dengan pembelajan sehingga bisa membantu meningkatkan hasil belajar siswa. Ketika interpersonal inntelensi siswa sudah baik, siswa sudah melakukan belajar kelompok dengan baik dan siswa sudah memanfaatkan internet dengan baik maka akan meningkatkan hasil belajar siswa.

Berdasarkan uraian di atas, hasil belajar siswa SMA Negeri 10 Malang dapat dibantu dengan interpersonal intelegensi, belajar kelompok dan pemanfaatan internet. interpersonal intelegensi, belajar kelompok dan pemanfaatan internet bila ketiganya sejalan dapat meningkatkan hasil belajar siswa di sekolah. Hasil penelitian menunjukkan bahwa ada pengaruh yang signifikan antara interpersonal intelegensi, belajar kelompok dan pemanfaatan internet terhadap hasil belajar siswa. Penelitian ini dapat dibuktikan melalui perhitungan statistika diperoleh tabel anova yang menunjukkan hasil uji $\mathrm{F}$ 4.928 dengan tingkat ,004b lebih kecil dari 0,05.

\section{Pengaruh Interpersonal Intelegensi, Belajar Kelompok, Dan Pemanfaatan Internet Terhadap Hasil Belajar.}

Berdasarkan hasil penelitian untuk mengetahui secara bersama-sama interpersonal intelegensi, belajar kelompok, dan pemanfaatan internet terhadap hasil belajar digunakan uji F. Hasil statistik menunjukan bahwa ada pengaruh yang signifikan secara simultan antara interpersonal intelegensi, belajar kelompok dan pemanfaatan internet terhadap hasil belajar. Interpersonal intelegensi, belajar kelompok dan pemanfaatan internet siswa kelas XI IPS SMA N 10 Malang sudah 
baik itu, hal ini diperoleh dari jawaban responden pada kuesioner mengenai interpersonal intelegensi, belajar kelompok dan pemanfaatan internet pada saat penelitian. Interpersonal intelegensi, belajar kelompok dan pemanfaatan internet sangat berpengaruh terhadap hasil belajar. Ketika interpersonal intelegensi siswa sudah baik maka akan mempermudah siswa untuk bergaul, berinteraksi dan berlajar bersama temannya mempermudah siswa itu untuk menerima, memahami, dan menghargai temannya. Karena ketika siswa sudah mau memahami, menghargai, menerima pendapat dari teman maka akan mempermudah siswa untuk belajar. Selain itu dari belajar kelompok, model pembelajaran yang digunakan oleh guru sangat membantu anak dalam proses belajar, karena dengan belajar kelompok siswa yang tidak aktif di kelas menjadi aktif, siswa yang malu bertanya menjadi tidak malu, siswa yang malas mengerjakan tugas jadi rajin karena motivasi dari teman lain. Serta dengan adanya pmanfaatan internet dapat mempermudah siswa untuk belajar, siswa bisa mencari materi atau reverensi lain selain buku yang disediakan guru di sekolah selain dari buku siswa bisa mencari materi di internet, menonton vidio-vidio yang yang berhubungan dengan pembelajan sehingga bisa membantu meningkatkan hasil belajar siswa. Ketika interpersonal inntelensi siswa sudah baik, siswa sudah melakukan belajar kelompok dengan baik dan siswa sudah memanfaatkan internet dengan baik maka akan meningkatkan hasil belajar siswa. Siswa yang belajar dengan tekun akan memperoleh hasil belajar yang baik pula. Hasil belajar di SMA N 10 Malang sangat baik. Sebagian besar siswa sudah mendapatkan nilai diatas KKM. Pencapaian hasil belajar yang baik dan memuaskan bisa membuat siswa mendapatkan pringkat dan lulusan terbaik.

\section{Pengaruh Interpersonal Intelegensi Terhadap Hasil Belajar}

Hasil penelitian mengenai pengaruh Interpersonal intelegensi terhadap hasil belajar menunjukkan bahwa tidak terdapat pengaruh yang signifikan secara parsial Interpersonal intelegensi terhadap hasil belajar yang diukur melalui sikap empati, sikap prososial, kesadaran diri, pemahaman situasi sosial, keterampilan pemecahan masalah. komunikasi efektif dan mendengarkan efektif.. Hasil penelitian ini dibuktikan melalui perhitungan statistika diperoleh tabel cofficients yang menunjukkan penelitian hasil uji $t$ dengan tingkat signifikan ,087>0,05. Berdasarkan penelitian Interpersonal intelegensi siswa sangat baik, hal ini diperoleh dari jawaban responden pada kuesioner mengenai Interpersonal intelegensi. Tetapi tidak berpengaruh terhadap hasil belajar karena peneliti lihat siswa zaman sekarang ketika pada saat bertemu tidak saling berintelaksi atau berkomunikasi karena masing-masing sibuk dengan media sosial masing-masing, ada siswa yang tidak mau bergaul dengan teman yang lain karena ada perbedaan-perbedaan tertentu. Oleh sebab itu interpersonal intelegensi tidak berpengaruh terhadap hasil belajar.

\section{Pengaruh Belajar Kelompok Terhadap Hasil Belajar}

Hasil penelitian mengenai pengaruh belajar kelompok terhadap hasil belajar siswa menunjukkan bahwa terdapat pengaruh yang signifikan secara parsial belajar kelompok terhadap hasil belajar siswa yang diukur melalui indikator, saling berrgantungan positif, tanggung jawab perseorangan komunikasi antara anggota dan evaluasi belajar kelompok. Belajar kelompok di SMA N 10 Malang sudah baik, siswa sudah melakukan belajar kelompok dengan baik, sehingga berpengaruh positif terhadap hasil belajar. Penelitian ini dibuktikan melalui perhitungan statistika diperoleh tabel coefficients yang menunjukkan hasil uji t dengan tingkat siginifikan 0,006 < 0,05 . 


\section{Pengaruh Pemanfaatan Internet Terhadap Prestasi Belajar}

Hasil penelitian mengenai pengaruh pemanfaatan internet terhadap hasil belajar, menunjukkan bahwa tidak terdapat pengaruh yang signifikan secara parsial pemanfaatan internet terhadap hasil belajar siswa yang diukur melalui indikator, berapa sering siswa mengakses internet, durasi waktu yang digunakan untuk mengakses internet, fasilitas-fasilitas internet apa saja yang digunakan untuk mengakses internet, mengerjakan tugas dan mendalami materi pembelajaran. Pemanfaatan internet siswa sangat baik, hal ini diperoleh dari jawaban responden pada kuesioner mengenai Pemanfaatan internet. Tetapi pemanfaatan internet tidaak berpengaruh terhadap hasil belajar kerena sesuai peneliti lihat siswa mengunakan internet bukan untuk belajar tetapi untuk bermain game, ketika guru menyuruh siswa untuk menonton video di internet yang berhubungan dengan pembelajaran tetapi siswa lebih tertarik nonton vidio-vidio yang lain, saat menggunakan facebook siswa tidak menggunakan untuk membahas permasalahan pembelajaran melaikan untuk membahasal hal sosial lainnya, oleh sebab itu pemanfaatan internet tidak berpengaruh terhadap hasil belajar. Penelitian ini dibuktikan melalui perhitungan statistika diperoleh tabel coefficients yang menunjukkan hasil uji t dengan tingkat signifikan 0,485>0,05.

\section{KESIMPULAN}

Berdasarkan hasil analisis yang telah dilakukan oleh peneliti, maka dapat ditarik beberapa kesimpulan bahwa terdapat pengaruh positif yang signifikan secara simultan interpersonal intelegensi, belajar kelompok, dan pemanfaatan internet terhadap hasil belajar siswa kelas XI IPS SMA N 10 Malang. Sedangkan untuk analisis secara parsial Pada interpersonal intelegensi tidak terdapat pengaruh secara parsial terhadap hasil belajar siswa kelas XI IPS SMA N 10 Malang. Belajar kelompok terdapat pengaruh positif secara parsial terhadap hasil belajar siswa kelas XI IPS SMA N 10 Malang. Dan pemanfaatan internet tidak terdapat pengaruh parsial terhadap hasil belajar siswa kelas XI IPS SMA N 10 Malang.

Bagi peneliti selanjutnya, penelitian ini diharapkan bisa membantu peneliti selanjutnya sebagai sumber belajar. Peneliti ini dapat digunakan sebagai masukan maupun perbandingan dalam melaksanakan penelitian yang sejenis terutama yang berkaitan dengan interpersonal intelegensi, belajar kelompok dan pemanfaatan internet. Dalam penelitian ini terdapat kekurangan yaitu dalam penyusunan indikator untuk kuesioner tidak berpedoman pada teori Bloom mengenai ranah kognitif yang terdiri dari enam tingkatan atau kategori yaitu: pengetahuan (knowlegde), pemahaman (comprehension), penerapan (application), analisis (analysis), sintesis (shyntesis), dan evaluasi (evaluation). Selain itu, kurangnya jurnal yang mendukung hasil penelitian yang menyatakan bahwa pengaruh tentang interpersonal intelegensi, belajar kelompok dan pemanfaatan internet tidak berpengaruh terhadap hasil belajar. Oleh kerena itu, diharapkan untuk peneliti selanjutnya yang meneliti variabel yang sama dan memiliki kesamaan dalam hasil penelitian, lebih banyak lagi mencari referensi yang mendukung hasil penelitiannya. 


\section{DAFTAR PUSTAKA}

Arikunto. 2010. Prosedur Penelitian Satuan Pendidikan Praktik. Jakarta PT RINEKA CIPTA

Abdurrahman, Mulyono. 2012. Pendidikan bagi Anak Berkesulitan Belajar. Jakarta: Rineka Cipta.

Azwar, S. 2011. Pengantar Psikologi Inteligensi.Yogyakarta: Pustaka Pelajar.

Cepi Safrudin \& Jabar. (2010). Mengenal Komputer. Fakultas Ilmu Pendidikan UNY.

Dalyono, M. 2012. Psikologi Pendidikan. Jakarta: Rineka Cipta

Dimyati \& Mudjiono. 2013. Belajar Dan Pembelajaran. Jakarta: Rineka Cipta.

Hamalik, Oemar. 2011. Kurikulum Dan Pembelajaran. Jakarta: PT. Bumi

Aksara.

Kadek Sukiati Arini. 2011. Pengaruh Tingkat Intelegensi dan Motivasi Belajar Terhadap Prestasi Belajar. Aneka Ilmu Semarang. Universitas Semarang

Garner, Howard. 2010. The Theory of Multiple Intelligence. New York. Basic Books.

Huda, Miftahul. 2012. Cooperative Learning. Yogyakarta: Pustaka Pelajar.

Muhibbin Syah.2010.Psikologi Pendidikan dengan pendekatan baru.Bandung:PT Remaja Rosdakarya

Roestiyah N.K. 2010. Strategi Belajar Mengajar. Jakarta: PT. Rineka

Rusman. 2012. Faktor-faktor yang mempengaruhi hasil belajar. Jakarta: PT. Bumi Aksara.

Rusman. 2011. Model-Model Pembelajaran: Mengembangkan Profesionalisme Guru, cetakan ke - 2, Jakarta: Rajagrafindo Persada.

Safaria. 2010. Interpersonal Intelligence: MetodePengembanganKecerdasan Interpersonal Anak. Yogyakarta : Amara Books.

Sagala. 2011. Konsep dan Makna Pembelajaran, Bandung: Alfabeta.

Sarwoko. 2011. Strategi Tulis Artikel Jurnal Internasional. Yogyakarta:

ANDI YOGYAKARTA

Sholikah dan shaifudin. 2013. Media Komunikasi. Yogyakarta: Andi Offset.

Slameto. 2010. Belajar dan Faktor-Faktor yang Mempengaruhinya.Jakarta: Rineka Cipta.

Sugiyono. 2011. Metode Penelitian Kuantitatif, Kualitatif dan RED. Bandung: Afabeta

Suprijono, A.2012. Cooperative Learning Teori dan Aplikasi PAIKEM. Yogyakarta: Pustaka Pelajar.

Susanto, Ahmad. 2014. Teori belajar dan pembelajaran. Jakarta. Kencana

Prenadi Media Group

Yaumi dan Ibrahim. 2013. "Pembelajaran Berbasis Kecerdasan Jamak". Jakarta: Prenadamedia Group

Zahid. 2013. Pengaruh Belajar Kelompok Terhadap Prestasi Belajar Bahasa Arab. Universitas Muhammadia Surakarta 